\title{
METODE TAHFIDZ AL-QUR'AN DI PONDOK PESANTREN MIFTAHUL HUDA II KABUPATEN CIAMIS
}

\author{
Dudi Badruzaman \\ STAI Sabili Bandung \\ Email: badruzaman.dudi@yahoo.com
}

\begin{abstract}
Abstrak. Tulisan ini membahas tentang "Metode Tahfidzal-Qur'an di Pondok Pesantren Miftahul Huda II Kabupaten Ciamis". Fokus kajiannya adalah metode yang digunakan Pondok Pesantren Miftahul Huda II Kabupaten Ciamis dalam membina santrinya mengikuti tahfizd al-Qur'an. Penelitian dilakukan dengan pendekatan kualitatif, Pengumpulan data dilakukan dengan teknik wawancara, dokumentasi, dan observasi. Hasil penelitian menemukan bahwa pondok pesantren Miftahul Huda II Kabupaten Ciamis menggunakan berbagai metode dalam membina santrinya mengikuti kegiatan tahfizd al-Qur'an, yaitu dengan cara; membaca secara cermat ayat per-ayat al-Qur'an yang akan dihafal dengan melihat mushaf secara berulang-ulang (an-nadzar), menghafal ayat per ayat secara berulang sehingga akhirnya hafal (al-wahdah), menyetorkan atau mendengarkan hafalan yang baru dihafal kepada seorang guru (talaqqi), menghafal sedikit demi sedikit al-Qur'an yang telah dibaca secara berulang-ulang (takrir) dan mendengarkan hafalan kepada orang lain, baik kepada teman maupun kepada jama'ah lain (tasmi').
\end{abstract}

Kata kunci: Al-Qur'an, Tahfidz, dan Pondok Pesantren

\section{Pendahuluan}

Al-Qur'an merupakan petunjuk dan pedoman bagi umat manusia dalam menghadapi segala persoalan hidup dan kehidupannya sepanjang zaman, yang tak layu oleh waktu dan tak lekang oleh zaman, serta - meminjam istilah Quraish Shihab - dapat berdialog dengan seluruh generasi manusia, guna memperoleh kebahagiaan hidup di dunia maupun akhirat. $^{1}$

Sebagai petunjuk dalam kehidupan umat Islam, al-Qur'an tidak hanya cukup dengan membaca dengan suara yang indah dan fasih, tetapi selain memahami harus ada upaya konkret dalam memeliharanya, baik dalam bentuk tulisan maupun hafalan. Al-Qur'an tidak boleh dibiarkan begitu saja sebagai koleksi atau apapun nama dan bentuknya, tanpa penjagaan dan pemeliharaan yang serius dari umatnya.

Umat Islam berkewajiban memelihara dan menjaganya, antara lain adalah dengan membaca (al-tilawah), menulis (al-kitabah) dan menghafal (attahfidz), sehingga wahyu tersebut

\footnotetext{
${ }^{1}$ Muhammad Quraish Shihab, dalam Pengantar, YunanYusuf, Corak Pemikiran Kalam Tafsir al-Azhar (Jakarta: Pustaka Panjimas, 1990), v.
}

senantiasa terjaga dan terpelihara dari perubahan dan penggantian, baik huruf maupun susunan kata- katanya sepanjang masa. Allah Swt. menyebutkan dalam firman-Nya: ${ }^{2}$

$$
\text { إنَّا نَخْنُ ذَزَّلْنَا الذِّكْرَ وَإِنَّا لَهُهُ لَحَافِظُونَ }
$$

Artinya: "Sesungguhnya Kami-lah yang menurunkan al-Qur'an, dan Sesungguhnya Kami benar-benar memeliharanya" (QS. al- Hijr : 9).

Berdasarkan ayat tersebut, Allah Swt.memberikan garansi bahwa dia senantiasa menjaga Al qur'an bukan berarti Allah Swt. menjaga secara langsung fase-fase penulisan al-Qur'an, tetapi melibatkan para hamba-Nya untuk ikut menjaga al-Qur'an tersebut. Salah satu bentuk realisasinya adalah Allah Swt. mempersiapkan manusia-manusia pilihan yang akan menjadi penghafal alQur'an dan penjaga kemurnian kalimat serta bacaannya. Sebab memelihara kesucian dengan menghafalkannya adalah pekerjaan yang terpuji dan amal yang mulia, yang sangat dianjurkan Rasulullah. ${ }^{3}$

2 Departemen Agama RI, Al-Qur'an dan Terjemahnya (Jakarta:Toha Putra, t.th), 391. Selanjutnya ayat-ayat diterjemahkan dengan referensi yang sama.

${ }^{3}$ Perguruan Tinggi Ilmu Al-Qur'an, Beberapa Aspek Ilmiah Tentang Qur'an (Jakarta: Litera 
Pada masa Nabi Muhammad Saw. menerima wahyu al-Qur'an dari Allah Swt., bangsa Arab sebagian besar buta aksara (tidak pandai membaca dan menulis). Mereka belum banyak mengenal kertas sebagai alat tulis seperti sekarang, begitu pula membacanya. Oleh karena itu, setiap Nabi Saw. menerima wahyu selalu dihafalnya, kemudian beliau menyampaikan kepada para sahabat dan diperintahkannya pula untuk menghafal dan menuliskan di batu-batu, pelepah kurma, kulit-kulit binatang dan apa saja yang bisa dipakai untuk menulisnya pada masa itu. Tradisi pemeliharaan al-Qur'an dalam bentuk hafalan khususnya terus berlanjut dari generasi ke generasi hingga sampai sekarang. ${ }^{4}$ Dorongan untuk menghafal al-Qur'an sendiri telah dijelaskan dalam firman-Nya:

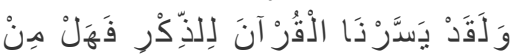

$$
\begin{aligned}
& \text { هُدَّكِرِ }
\end{aligned}
$$

Artinya: "Dan sesungguh, telah kami mudahkan al-Qur'an untuk peringatan maka adakah orang yang mengambil pelajaran?"(QS. al-Qamar: 22).

Ayat ini mengindikasikan kemudahan dalam menghafal al-Qur'an, karena Allah Swt. akan memberi pertolongan dan kemudahan bagi para penghafal al-Qur'an. Sebab memelihara kesucian dengan menghafalkannya adalah pekerjaan yang terpuji dan amal yang mulia, yang sangat dianjurkan agama. Dalam sebuah hadits redaksi dari Bukhari disebutkan bahwa "Perumpamaan orang yang memnbaca al-Qur'an dan menghafalnya adalah bersama para maliakat yang mulia dan ta'at" Bahkan menghafal al- Qur'an merupakan salah satu metode yang digunakan Rasulullah Saw. dalam menerima wahyu melalui perantaraan Jibril as.

Menghafal al-Qur'an bukanlah tugas dan perkara yang mudah, artinya

Antarnusa, 1986), 137.

4 Muhaimin Zen, Tata Cara/Problematika Menghafal Al- Qur'an dan PetunjukPetunjuknya (Jakarta: PT Maha Grafindo, 1985), 5-6. tidak semudah membalikkan telapak tangan. Salah satu upaya terpenting diperhatikan dalam pembinaan tahfizh alQur'an adalah metode. ${ }^{5}$ Sebab metode mempunyai peranan penting dan sangat dibutuhkan. Dengan adanya metode akan bisa membantu seseorang untuk menentukan keberhasilan belajar menghafal al-Qur'an dan meningkatkan hafalannya secara terprogram. Di samping juga diharapkan nantinya dapat membantu hafalan menjadi efektif.

Di zaman yang serba canggih pada saat ini, ditemukan banyak sekali metode yang bisa digunakan untuk membantu proses penghafalan al-Qur'an. Metode efektif yang digunakan penghafalan alQur'an beragam, ada dengan cara; membaca secara cermat ayat-ayat alQur'an yang akan dihafal dengan melihat mushaf secara berulang-ulang (an-nadzar), menyetorkan atau mendengarkan hafalan yang baru dihafal kepada seorang guru (talaqqi), menghafal sedikit demi sedikit al-Qur'an yang telah dibaca secara berulang-ulang (takrir), mendengarkan hafalan kepada orang lain baik kepada teman maupun kepada jama'ah lain (tasmi'), dan sebagainya. Kemudian dalam melaksanakan metode tahfidz alQur'an hendaknya dipandu dan dibimbing lansung oleh pemandu tahfidz yang berkompeten dalam penghafalan alQur'an, supaya hafalan yang sudah didapatkan bisa dipantau dan dibina oleh pemandu tahfidz bila ada kesalahan dan sebagainya.

Demikian pula di Kabupaten Kampar khususnya, pada masa sekarang telah tumbuh subur lembaga-lembaga pendidikan Islam yang memberikan kesempatan kepada putra-putri di daerahnya mendalami nilai-nilai agama

\footnotetext{
5 Winarno Surakhmad menyebutkan metode adalah cara yang di dalam fungsinya merupakan alat untuk mencapai tujuan tertentu, makin baik metode itu makin efektif pula pencapaian tujuan. Lihat Winarno Surakhmad, Pengantar Interaksi Mengajar-Belajar Dasar dan Teknik Metodelogi Pengajaran (Bandung: Tarsito, 1982), 96.
} 
guna membentuk kepribadian muslim yang beriman dan bertakwa kepada Swt., berakhlak mulia, bermanfaat bagi kemajuan pembangunan bangsa dan negara. Misalnya, pesantren Daarun Nahdhah, Daarul Qur'an, Anshar alSunnah, Daar al-Salafi, Sabil al-Salam, alTaufik, dan lainnya. Selain memberikan kesempatan kepada para santrinya mendalami nilai-nilai agama, di pesantren- pesantren tersebut juga mendidik para santrinya menguasai ilmu al-Qur'an dengan melaksanakan program unggulan membimbing santrinya menjadi huffazh (para penghafal alQur'an).

Untuk mencapai tujuannya di bidang pembinaan tahfidz al-Qur'an dibutuhkan suatu strategi dan cara yang cocok, sehingga tujuan yang diinginkan dapat tercapai. Demikian pula dengan pelaksanaan menghafal al-Qur'an, memerlukan suatu metode dan teknik yang dapat memudahkan usaha-usaha tersebut, sehingga dapat berhasil dengan baik. Oleh karena itu, metode merupakan salah satu faktor yang turut menentukan keberhasilan dalam menghafal al-Qur'an, khususnya bagi para santri pondok pesantrem di Kabupaten Kampar.

\section{Metode Penelitian}

Penelitian ini adalah penelitian lapangan (field research), karena kegiatan ini dilakukan di pondok pesantren Miftahul Huda II Kabupaten Ciamis. Secara umum yang menjadi alasan penulis memilih lokasi Kabupaten Kampar, selain karena pertimbangan waktu dan biaya ada beberapa pertimbangan lain; pertama, karena penduduk di Kabupaten Kampar mayoritas beragama Islam, dan mereka taat menjalankan ajaran-ajaran agama dalam kehidupan sehari-hari. Kedua, di daerah ini terdapat beberapa Pondok Pesantren yang mempunyai program unggulan di bidang tahfidz al-Qur'an (penghafalan al-Qur'an) serta telah mendapat predikat baik di bidang agama khususnya pembelajaran al-Qur'an. Ketiga, sampai saat penulis melakukan penelitian pendahuluan belum ada penelitian spesifik yang membahas tentang metode tahfidz al-Qur'an di Kabupaten ciamis tersebut.

Penelitian ini menggunakan pendekatan kualitatif, yaitu jenis pendekatan penelitian yang tidak melibatkan perhitungan. Sumber data yang diperlukan dalam penelitian ini terdiri dari data primer dan data sekunder. Data sekunder diperoleh dari bahan-bahan kepustakaan, meliputi bahan hukum primer dan bahan hukum sekunder. Sedangkan data primer diperoleh dari nara sumber di lapangan melalui wawancara, observasi, dan dokumen. Dalam wawancara peneliti berinteraksi langsung dengan informan wawancara dilakukan terhadap kyai, pimpinan pondok, santri, dan ustad/ ustadzah pengampu kegiatan tahfizd.

\section{Pondok Pesantren Sebagai Setting Penelitian di Pesantren Miftahul Huda II Kabupaten Ciamis}

Pada bagian ini akan digambarkan sekilas tentang kondisi umum pondok pesantren disebut di atas. Kondisi umum yang penulis maksud adalah uraian singkat mengenai situasi dan kondisi Pondok Pesantren di Kabupaten Ciamis, yang kemudian dijadikan lokasi penelitian oleh penulis yang meliputi; sejarah berdirinya, tujuan berdiri, visi dan misi, dan metode pelaksanaan kegiatan tahfidz alQur'an yang diterapkan pondok pesantren bagi santrinya.

\section{a. Pondok Pesantren Al- Hasan}

Berdasarkan observasi dan wawancara, Pondok Pesantren Al-hasan berdiri pada tahun 1990 yang dipelopori oleh KH. Syarif Hidayat, Pesantren ini terletak di jantung ibu kota Kabupaten ciamis, tepatnya Jl. Jend. Ahmad yani. Berdirinya pesantren ini dilatari oleh keinginan pimpinan/pendiri pondok dan semangat masyarakat ciamis khususnya untuk mendirikan lembaga pendidikan yang dapat menampung generasi-generasi yang Islamy atau mencetak ulama.

$\begin{array}{ccr}\text { Sebagai } & \text { sebuah } & \text { lembaga } \\ \text { pendidikan } & \text { keagamaan, } & \text { Pondok }\end{array}$


Pesantren Al Hasan telah berperan aktif dalam mencerdaskan kehidupan bangsa. Selain membekali para santrinya dengan pengetahuan agama dan umum, juga keterampilan membaca kitab kuning dan hafalan al-Qur'an. Para santri diwajibkan memiliki hafalan al-Qur'an sesuai dengan peringkatnya.

Adapun Visi Pondok Pesantren Al Hasan adalah menjadi lembaga pendidikan yang berkualitas, kreatif, dan inovatif pada semua disiplin ilmu untuk menampilkan keterpaduan IMTAQ (Iman dan Taqwa) dan IPTEK (Ilmu Pengetahuan dan Teknologi). Sedangkan misinya, adalah:

a) Melaksanakan pendidikan dengan sistem keterpaduan pada bidang kurikulum, pengelolaan dan qudwah.

b) Mewujudkan peserta didik yang berilmu, mandiri, dan berjiwa wiraswasta yang mampu menciptakan lapangan kerja di masyarakat.

\section{b. Pondok Pesantren Al Muawannah}

Berdasarkan observasi dan wawancara, diperoleh informasi bahwa Pondok Pesantren Anshar As-Sunnah berdiri pada tahun 2001 yang dipelopori oleh KH. Maman, Pesantren ini terletak di Desa Sirnabaya Kecamatan Rajadesa, tepatnya Jl. Pasar rajadesa. Berdirinya pesantren ini dilatari oleh keinginan pimpinan/pendiri pondok dan semangat masyarakat setempat untuk mendirikan lembaga pendidikan yang dapat menampung generasi-generasi yang Islami atau mencetak ulama.

Adapun visi dan misi serta tujuan Pondok Pesantren Al Muawannah adalah terwujudnya masyarakat Madrasah Tsanawiyah Al Muawannah yang ta'at, dinamis, rukun, berprestasi dan terampil, serta terwujudnya Madrasah Tsnawiyah Al Muawannah sebagai lembaga pendidikan yang berkualitas dan unggul di Propinsi jawa barat dalam membentuk siswa/siswi yang hafidz dan hafidzah. Sedangkan misinya, antara lain:

a. Mewujudkan masyarakat yang Islami, berwawasan yang luas, berakhlak mulia, beriman dan bertaqwa.

b. Mewujudkan ketenagaan yang bekualitas, cerdas, loyal, inovatif, dan kreatif.

c. Mewujudkan masyarakat madrasah yang terampil serta dapat dirasakan mamfaatnya oleh masyarakat.

\section{Metode Pelaksanaan Tahfidz Al-Qur'an di Pondok Pesantren Miftahul Huda II Kabupaten Ciamis}

Metode atau yang biasa disebut juga cara merupakan hal sangat penting dalam mencapai keberhasilan, karena berhasil tidaknya suatu tujuan ditentukan oleh metode yang merupakan bagian integral dalam sistem pembelajaran. Banyak metode yang mungkin bisa dikembangkan dalam rangka mencari alternatif terbaik untuk menghafal alQu'an, bahkan bisa memberikan bantuan kepada para penghafal dalam mengurangi kesulitan menghafal alQur'an.

Kegiatan Tahfidz al-Qur'an pada Pondok Pesantren Miftahul Huda II Kabupaten Ciamis merupakan kegiatan yang wajib diikuti para santri. Bahkan ada yang memasukkan tahfidz ini ke dalam komponen mata pelajaran pondok. Kegiatan penghafalan al-Qur'an tidaklah sama dan semudah mengajarkan mata pelajaran lain. Masing-masing pesantren melaksanakan kegiatan tahfidz al-Qur'an dengan metode yang berbeda.

Berdasarkan observasi dan wawancara yang dilakukan kepada beberapa orang pengasuh dan peserta tahfidz al-Qur'an di Pondok Pesantren Miftahul Huda II Kabupaten Ciamis, didapati informasi bahwa metode pelaksanaan Tahfidz al-Qur'an dari masing-masing pesantren dapat diekspresikan sebagai berikut:

Penghafalan al-Qur'an dengan cara menghafal ayat per-ayat secara kolektif, yakni ayat-ayat dihafal secara kolektif atau bersama-sama, dipimpin seorang 
instruktur. Caanya pertama, instruktur membacakan satu ayat atau beberapa ayat dan santri menirukan secara bersama-sama. Kedua, instruktur membimbingnya dengan mengulang kembali ayat-ayat tersebut dan santri mengikutinya. Setelah ayat-ayat itu dapat mereka baca dengan baik dan benar, selanjutnya mereka mengikuti bacaan dengan sedikit demi sedikit mencoba melepaskan mushaf (tanpa melihat mushaf) dan demikian seterusnya sehingga ayat-ayat yang sedang dihafalnya itu benar- benar sepenuhnya masuk dalam bayangannya.

$$
\text { Pondok Pesantren yang }
$$

menggunakan metode seperti ini adalah Pondok Pesantren Al hasan, yang mana ustadz/pengampu membacakan ayatayat tersebut di hadapan santrinya, kemudian para santri menirukan bacaan ustazd/pengampu secara bersama-sama dan berulang-ulang, sehingga secara perlahan-lahan santri bisa membaca ayatayat yang sedang dihafalnya tanpa melihat mushaf karena benar-benar dalam sudah ada dalam bayangannya. Cara ini termasuk metode yang baik untuk dikembangkan, karena akan dapat menghilangkan kejenuhan, di samping akan membantu menghidupkan daya ingat terhadap ayat-ayat yangdihafalnya.

Pelaksanaan tahfidz al-Qur'an
dengan menggunakan metode wahdah, yakni menghafal satu per satu terhadap ayat-ayat yang hendak dihafalnya. Untuk mencapai hafalan awal setiap ayat bisa dibaca sebanyak sepuluh kali, atau lebih sehingga proses ini mampu membentuk pola dalam bayangannya. Dengan demikian, penghafal akan mampu mengkondisikan ayat-ayat yang dihafalnya bukan saja dalam bayangan akan tetapi hingga membentuk gerak refleks pada lisannya. Setelah benarbenar hafal barulah dilanjutkan pada ayat-

\footnotetext{
${ }^{6}$ W. Ahsin Al-Hafizh, Bimbingan Praktis Menghafal Al- Qur'an (Jakarta: Bumi Aksara, 2000), 63.
}

ayat berikutnya dengan cara yang sama, demikian seterusnya hingga mencapai satu muka.

Cara seperti ini diikuti oleh Pondok Pesantren Al muawannah, di mana santri menghafal ayat per ayat secara sendiri-sendiri dan berulang, sehingga akhirnya bisa hafal. Kemudian untuk muraja'ah digunakan cara takrir, artinya santri mengulang kembali hafalan yang sudah pernah dihafalkan untuk menjaga dari lupa dan salah. Hafalan yang sudah pernah dipedengarkan kepada ustadz/ ah atau kiyai diulang-ulang terus dengan dilakukan sendiri ataupun meminta bantuan orang lain untuk mendengarkan dan mengoreksi.

Cara yang seperti ini termasuk ke dalam metode yang banyak digunakan oleh para penghafal al-Qur'an, karena akan memudahkan penghafal, kemudian bacaan maupun hafalannya bisa dikoreksi oleh ustadz/pengampu secara langsung.

Pembinaan tahfidz al-Qur'an dengan menggabungkan antara metode wahdah dengan metode jama', artinya santri di samping menghafal sendiri-diri juga menghafal secara bersama-sama, kemudian muraja'ah-nya disetorkan kepada uztadz/ pengampu tahfidz. Cara yang seperti ini termasuk metode yang efektif dan banyak digunakan oleh para pencinta hafal alQur'an. Selain memudahkan penghafal mengkondisikan ayat-ayat yang akan dihafalnya, tetapi juga dapat membentuk gerak refleks pada lisannya karena senantiasa terbayang dalam ingatannya.

Cara seperti ini terdapat pada Pondok Pesantren darussalam, yang mana ustazd/pengampu tahfidz melaksanakan kegiatan tahfidz secara terprogram dan terpantau, di samping untuk menambah/ memerlancar hafalan juga membaiki bacaan santri.

Kegiatan pembinaan tahfidz alQur'an menggunakan metode halaqah, di bawah pengawasan seorang musyrif (guru pengampu) per halaqah. Mayoritas santri 
menghafal ayat per ayat, metode ini dilaksanakan ketika mereka sedang membuat hafalan baru, biasanya mereka terapkan pada waktu dini hari setelah qiyamul lail. Kemudian setoran hafalan di lakukan setelah shalat subuh dengan cara membaca satu-persatu kemudian didengarkan oleh seorang musyrif guna membetulkan bacaan santri dari segi tajwid maupun kelancaran hafalannya, sebagaimana terdapat pada Pondok Pesantren Dar As-Salaf.

Meskipun demikian, menurut hemat penulis metode jama' merupakan metode yang efektif dalam penghafalan alQur'an, karena santri menghafal ayat-ayat secara kolektif atau bersama- sama, dipimpin seorang musyrif (pengampu) kemudian santri mengikuti bacaan musyrif secara berulang termasuk metode yang baik untuk dikembangkan, karena akan dapat menghilangkan kejenuhan, di samping akan membantu menghidupkan daya ingat terhadap ayatayat yang dihafalnya.

Sedangkan waktu penghafalan pada masing- masing pesantren dilaksanakan setelah shalat maghrib dan shubuh, karena waktu ini yang lebih efektif. Akan tetapi, biasanya tak jarang para santri menambah waktu untuk muraja'ah di luar waktu yang telah disediakan, umpamanya 30 menit setelah shalat ashar, atau 30 menit setiap sebelum waktu melaksanakan shalatshalat fardhu berjama'ah. Bagi santri yang tinggal di asrama maupun tinggal di luar asrama (rumah) wajib menyetor hafalannya. Setoran hafalan tersebut, ustadz pengampu menunjuk santri satu persatu untuk membacakan hafalannya dan diperdengarkan oleh seluruh santri lainnya.

Sementara muraja'ah hafalannya terbagi dua pula; pertama muraja'ah individu dan muraja'ah bersama-sama. Muraja'ah individu tergantung individu masing mengatur jadwal dan waktu untuk muraja'ah-nya. Sedangkan muraja'ah bersama-sama yaitu di dalam kelas dengan beranggotakan kelas itu sendiri. Biasanya waktu muraja'ah adalah setelah semua anggota kelas menyetorkan hafalan ke guru tahfizh-nya dengan cara membaca secara bersama-sama hafalan yang telah mereka hafal.

\section{Faktor Pendukung dan Penghambat Pelaksanaan Tahfidz al-Qur'an di Pondok Pesantren Miftahul Huda II Kabupaten Ciamis}

Seperti dimaklumi bahwa kegiatan penghafalan al-Qur'an di pondok pesantren merupakan program penting dan wajib diikuti oleh setiap santri. Pelaksanaan kegiatan penghafalan alQur'an tidaklah sama dan semudah mengajarkan mata pelajaran lain. Pembelajaran di pondok pesantren memiliki tujuan untuk membentuk kepribadian muslim seutuhnya dalam mencapai kebahagiaan hidup di dunia dan akhirat. Demikian juga kegiatan tahfidz alQur'an, bertujuan agar santrinya menjadi huffadz (para penghafal) alQur'an.

Akan tetapi, setiap kegiatan apapun bentuknya pasti ada terdapat faktor pendukung maupun penghambat, baik yang datangnya dari dalam maupun dari luar. Begitu pula dalam kegiatan menghafal al-Qur'an, ada banyak faktor yang mempengaruhi, yaitu berupa faktor pendukung dan ada pula berupa faktor penghambat bagi para penghafal al-Qur'an. Maksud faktor pendukung di sini, penghafal al- Qur'an lebih memudahkan dirinya dalam menguasai hafalan al-Qur'an yang ia tekuni. Sedangkan faktor penghambat, maksudnya penghafal merasa kesulitan atau merasakan ada hambatan dalam proses menghafal al-Qur'an.

Berdasarkan observasi dan wawancara peneliti, diperoleh informasi bahwa santri yang bersekolah di Pondok Pesantren Miftahul Huda II Kabupaten Ciamis tidak semuanya yang tinggal di asrama seperti Pondok Pesantren Al hasan. Sebagian santrinya ada yang tinggal di rumah dan sebagian besar lainnya tinggal dalam asrama. Dalam hal ini, peneliti hanya akan mengemukakan faktor pendukung dan penghambat 
pelaksanaan tahfidz al-Qur'an bagi santri yang tinggal di asrama, termasuk juga pada pondok-pondok pesantren lain yang dijadikan lokasi penelitian.

Dari beberapa penuturan para pengajar/ ustadz pengampu tahfidz di pondok pesantren tersebut, ada beberapa faktor pendukung dan penghambat pelaksanaan tahfidz al-Qur'an, meliputi santri dan tenaga pengajar, metode, serta waktu pelaksanaannya. Untuk lebih jelasnya, berikut ini peneliti kemukakan faktor-faktor tersebut, yaitu:

Faktor pendukung bagi santri dalam mengikuti kegiatan tahfidz, antara lain:

a. Proses penghafalan dapat dipantau lansung oleh ustadz/pengampu, sehingga hafalan santri akan menjadi lebih mudah disima' atau dikontrol, begitu juga tahsin bacaannya.

b. Selalu termotivasi karena temanteman yang kesehariannya samasama menghafal, sehingga santri mudah untuk saling muroja'ah hafalan antar sesama.

c. Metode tahfidz yang mereka gunakan dapat membantu santri dalam menghafal, karena santri mengahafal ayat per ayat secara sendiri-sendiri maupun secara bersama-sama.

d. Pengaturan waktu menghafal alQur'an yang ditetapkan pondok pesantren merupakan salah satu kunci keberhasilan dalam menghafal al-Qur'an, karena di samping dapat menjaga suasana yang kondusif juga para santri memiliki disiplin dalam menghafal al-Qur'an.

Sementara faktor penghambat bagi santri pula dalam mengikui kegiatan tahfidz, antara lain:

a. Sering muncul kemalasan dan kebosanan menghafal al-Qur'an, karena padatnya waktu yang digunakan santri dalam kegiatan formal di sekolah mulai dari pagi hingga siang hari. b. Kurangnya minat santri muraja'ah hafalan, sehingga santri sering lupa bacaan yang sudah hafal sebelumnya, di samping juga karena kemampuan dan semangat belajar yang tidak sama.

c. Banyak yang mengantuk, terutama di pagi hari sesudah shalat shubuh.

Faktor penghambat seperti disebut di atas, kelihatannya tidak jauh berbeda dengan apa yang diungkapkan oleh Mukhlisoh Zawawie bahwa hambatanhambatan yang dihadapi oleh calon seorang hafidz adalah sibuk dan tidak memiliki banyak waktu, hati tidak jernih dan kurang fokus karena problematika hidup, bosan dan malas ketika memulai hafalan atau di tengah hafalan, faktor usia, tidak percaya diri karena hafal al- Qur'an adalah anugerah Allah, lemah ingatan, takut lupa, dan berdosa. ${ }^{7}$

\section{Upaya Mengatasi Hambatan Dalam Pelaksanaan Metode Tahfidz al-Qur'an di Pondok Pesantren Miftahul Huda II Kabupaten Ciamis}

Berdasarkan hasil observasi dan wawancara dengan beberapa orang ustadz pengampu tahfidz al-Qur'an, didapatkan informasi bahwa langkah dan upaya yang mereka lakukan untuk mengatasi hambatan dan kekurangan dalam melaksanakan kegiatan tahfidz al-Qur'an, antara lain:

a. Memberikan motivasi dan pembinaan kepada santri agar mereka tetap rajin, bersemangat dan istiqomah dalam menghafal alQur'an.

b. Memberikan berupa reward bagi santri yang berprestasi hafal 30 juz, yaitu berupa umroh gratis dan didaftarkan di Universitas Islam Madinah, seperti yang dilakukan oleh pimpinan Pondok Pesantren Anshar Al-

\footnotetext{
7 Mukhlisoh Zawawie, P-M3 Al-Qur'an Pedoman Membaca, Mendengar, dan Menghafal Al-Qur'an (Solo:Tinta Medina, 2011), 83-88.
} 
Sunnah.

c. Selain memotivasi dan pembinaan, juga adanya hukuman yang mendidik sifatnya, yaitu tidak akan memberikan ijazah pondok bagi santri yang belum atau tidak menyetorkan hafalan wajibnya kepada uztadz pengampu, seperti yang diterapkan oleh Pondok Pesantren Sabil As-Salam, Daarun Nahdhah, Dar As- Salafy, dan AtTaufiq.

\section{Kesimpulan}

Berdasarkan hasil penelitian dapat disimpulkan bahwa metode Tahfidzl al-Qur'an yang digunakan Pondok Pesantren Miftahul Huda II Kabupaten Ciamis cukup variatif dan baik. Ada yang menggunakan metode wahdah (menghafal per ayat), metode sima'i (menyima' bacaan al- Qur'an), dan ada pula yang memakai metode jama'i (menghafal bersama-sama). Penerapan metode tersebut cukup efektif, karena di samping memberikan kemudahan bagi santri, juga bisa membuat santri cepat dalam menghafal dan hafalannya bisa lebih terjaga.

\section{Daftar Pustaka}

Abdurrabi Nawabuddin. Teknik Menghafal al- Qur'an. Bandung: CV. Sinar Baru, 1991.

Abdurrahman Assegaf. Pendidikan Islam di Indonesia. Jogjakarta: SUKAPress, 2007.

Ahmad E. Koswara. Metode Efektif Menghafal Al-Qur'an. Jakarta: CV. Tri Daya Inti, t.th.

Ahmad Salim Badwilan. Panduan Cepat Menghafal Al-Qur'an. Yogyakarta: Diva Press, 2009.

Departemen Agama RI. Al-Qur'an dan Terjemahnya. Jakarta: Toha Putra, t.th.

al-Baghdadi, Khatib. al-Jaami' liakhlaqi ar-Rawi wa Adab As-Sami'. Juz I. Beirut: Dar al- Fikr, t.th.

Hasbullah. Sejarah Pendidikan Islam di Indonesia: Lintasan Sejarah Pertumbuhan dan Perkembangannya. Jakarta: PT. Grafindo Persada, 1999.

Ibn Hanbal, Abu Abdillah Muhammad bin Ahmad. Musnad Imam Ahmad. Juz III. Beirut: Dar al-Fikr, t.th.

Koentjaraningrat. Metode-metode Penelitian Masyarakat. Cet. VII. Jakarta: Sarasin, 1996.

Lexy J. Moloeng. Metode Penelitian Kualitatif. Bandung: Remaja Rosdakarya, 2001.

Marwan Saridjo, dkk. Sejarah Pondok Persantren di Indonesia. Jakarta: Dharma Bhakti, 1982.

Muhaimin Zen. Tata Cara atau Problematik Menghafal AlQur'an dan PetunjukPetunjuknya. Jakarta: PT Maha Grafindo, 1985.

Muhammad Quraish Shihab, Dalam Pengantar. Yunan Yusuf. Corak Pemikiran Kalam Tafsir al-Azhar. Jakarta: Pustaka Panjimas, 1990.

Muhammad Yunus. Kamus ArabIndonesia. Cet ke-3. Jakarta: Hidakarya Agung, 1990.

Mujamil Qomar. Strategi Baru Pengelolaan Lembaga Pendidikan Islam; Manajemen Pendidikan Islam. Jakarta: Erlangga, 2007.

Mukhlisoh Zawawie. P-M3 Al-Qur'an Pedoman Membaca, Mendengar, dan Menghafal Al- Qur'an. Solo: Tinta Medina, 2011.

Nawabuddin, Abdurrabi. Teknik Menghafal al- Qur'an. Bandung: CV. Sinar Baru, 1991.

Noeng Muhadjir. Metodologi Penelitian Kualitatif. Cet. 7. Yogyakarta: Rake Sarasin, 2000.

Nur Faizin Muhith. Semua Bisa Hafal AlQur'an. Surakarta: al-Qudwah, 2013.

Oemar Hamalik. Metode Belajar dan Kesulitan- kesulitan Belajar. Bandung: Tarsito,1983. 
Perguruan Tinggi Ilmu Al-Qur'an. Beberapa Aspek Ilmiah Tentang Qur'an. Jakarta: Litera Antarnusa, 1986.

al-Qazwini, Abu Abdullah Muhammad bin Yazid bin Majah al-Rabi'i. Sunan Ibn Majah. Juz

Beirut: Dar al-Fikr, t.th. Al-Qur'an alKarim.

Ridwan Nasir. Mencari Tipologi Format Pendidikan Ideal; Pondok rta: CV.Haji Masagung, 1986.
Pesantren di Tengah Arus Perubahan. Yogjakarta: Pustaka Pelajar, 2008.

Sa'dullah. 9 Cara Cepat Menghafal AlQur'an. Depok: Gema Insani, 2012.

Suharsimi Arikunto. Prosedur Penelitian suatu Pendekatan Praktek. Cet. 12. Jakarta: Rineka Cipta, 2002.

Syahruddin, Hanafie, Abdullah Abud S. Mimbar

Jaka 